\title{
Zastosowanie komunikacji elektronicznej w mediacjach w administracji publicznej
}

\section{Wprowadzenie}

W świetle obecnie obowiązujących przepisów w mediacjach toczących się w trakcie postępowania administracyjnego korzystanie z możliwości, jakie daje komunikacja elektroniczna, jest dopuszczalne prawnie. Ze względu jednak na to, że zarówno mediacje w procedurze administracyjnej, jak i wykorzystanie możliwości, jakie daje w postępowaniu administracyjnym komunikacja elektroniczna, są nowościa, oba te zagadnienia wymagają podjęcia studiów pozwalających na odpowiedź na rodzące się w takich przypadkach wątpliwości.

Artykuł jest próbą odpowiedzi na pytania wiążące się z zastosowaniem $w$ mediacjach $w$ trakcie postępowania administracyjnego internetowych form komunikacji ${ }^{1}$. Przede wszystkim chodzi o wskazanie, jaki może być zakres wykorzystania komunikacji elektronicznej w świetle

${ }^{1} \mathrm{~W}$ polskim porządku prawnym funkcjonuje pojęcie „środków komunikacji elektronicznej". Definicja legalna tego pojęcia znajduje się w art. 2 pkt 5 Ustawy z dnia 18 VII 2002 r. o świadczeniu usług drogą elektroniczną (Dz.U. Nr 144, poz. 1204 ze zm.), który określa tym mianem rozwiązania techniczne, w tym urządzenia teleinformatyczne i współpracujące z nimi narzędzia programowe, umożliwiające indywidualne porozumiewanie się na odległość przy wykorzystaniu transmisji danych między systemami teleinformatycznymi, a w szczególności pocztę elektroniczną. W niniejszym opracowaniu problem potraktowany został nieco szerzej. Chodzi raczej o próbę analizy samego faktu komunikacji elektronicznej, która może znaleźć zastosowanie w mediacjach prowadzonych w trakcie postępowania administracyjnego, jako zjawiska społecznego. Zostanie więc przeprowadzona próba analizy prakseologicznych uwarunkowań i kulturowego kontekstu tego typu komunikacji w mediacjach stosowanych w obszarze działania organów administracji publicznej. 
obecnych regulacji i jakie formy tej komunikacji są obecnie prawnie dopuszczalne. Podjęto także próbę identyfikacji narzędzi komunikacji elektronicznej, które warto byłoby zaadaptować do mediacji w postępowaniu administracyjnym, ewentualnie tego, jakie rozwiązania należałoby rozwinąć lub zaprojektować, by komunikacja między urzędem, mediatorem a stronami była efektywna i zgodna z założeniami prakseologicznymi instytucji mediacji. Ważną kwestią poruszoną w niniejszym opracowaniu jest również umiejscowienie mediacji elektronicznych w obszarze tzw. e-administracji.

\section{Ustawowe założenia proceduralne mediacji w sprawach administracyjnych - w stronę elastyczności kontaktów organów administracji publicznej z adresatami jej działań}

Mediacje w postępowaniu administracyjnym, znajdujące podstawę prawna w przepisach art. 13 oraz regulowane przepisami art. 96a-96n Ustawy z dnia 14 czerwca 1960 r. Kodeks postępowania administracyjne$\mathrm{go}^{2}$, ze swojego założenia są elastyczną formą rozwiązywania konfliktów ujawniających się w tym postępowaniu. Można traktować je również jako dogodne narzędzie dochodzenia do konsensusu w kształtowaniu treści przyszłego rozstrzygnięcia zarówno w postępowaniu przed organem pierwszej, jak i drugiej instancji.

Ustawodawca nałożył przepisem art. $13 \S 1$ k.p.a. na organy administracji publicznej obowiązek dążenia do polubownego rozstrzygania kwestii spornych oraz polubownego ustalania praw i obowiązków będących przedmiotem postępowania w sprawach, których charakter na to pozwala, ale pozostawił znaczny zakres swobody w decydowaniu o sposobach osiągnięcia tego celu. Środkiem do tego prowadzącym, w myśl powołanej tu regulacji, mogą być mediacje jako jedna z postaci działań skłaniających strony mające sporne interesy do zawarcia ugody. Poza mediacjami możliwe jest wykorzystanie także innych alternatywnych metod rozwiązywania sporów mieszczących się w zakresie tzw. ADR (Alternative Dispute Resolution), np. negocjacji wspomaganych albo konferencji pojednawczej - celem ustawodawcy było stworzenie podstawy prawnej pozwalającej na względnie odformalizowany i niezbiurokratyzowany sposób rozstrzygania konfliktów mających związek z praktyką stosowania prawa administracyjnego.

\footnotetext{
${ }^{2}$ Tekst jedn. Dz.U. 2017, poz. 1257, dalej „k.p.a.” lub „Kodeks”.
} 
Nowa formuła postępowania administracyjnego ma sprzyjać przyjaznemu rozwiązywaniu sporów między jednostką a administracją czego konsekwencją ma być spadek liczby skarg wnoszonych do sądów³. Pisze o tym m.in. J. Wegner-Kowalska, zdaniem której udział mediatora $\mathrm{w}$ sporze $\mathrm{z}$ administracją umożliwi zidentyfikowanie problemu, ustalenie granicznych warunków negocjacji oraz pola ewentualnego porozumienia. Rolą mediatora może być też w nierzadkich przecież przypadkach, gdy spór wynika z niedostatku wiedzy prawniczej strony postępowania, spokojne wyjaśnienie stronie istoty przysługujących jej praw i ciążących na niej obowiązków i ewentualnie ograniczenie kontestowania uzasadnionych w sposób oczywisty rozstrzygnięć ${ }^{4}$.

Przepisem wprost ustanawiającym standard elastyczności postępowania w takich przypadkach jest $\S 2$ art. 13 k.p.a., zgodnie z którym organy administracji publicznej mogą podejmować wszystkie uzasadnione na danym etapie postępowania czynności umożliwiające przeprowadzenie mediacji lub zawarcie ugody. Procedura postępowania podczas mediacji została unormowana w przepisach rozdziału 5a k.p.a. - gdzie przewiduja ją przepisy art. 96a-96n. W mediacjach podejmowanych na podstawie tych regulacji stosuje się ponadto przepisy art. 117-121 k.p.a., dotyczące ugody administracyjnej.

Obowiązujący w Polsce standard prowadzenia mediacji w postępowaniu administracyjnym odpowiada więc założeniom określonym w Rekomendacji Komitetu Ministrów Rady Europy z dnia 5 września 2001 r. nr R (2001)9 o alternatywnych środkach rozstrzygania sporów sądowych pomiędzy władzami administracyjnymi a osobami prywatnymi ${ }^{5}$, w której, jak piszą P. Sołtysiak i E. Wójcicka, zaproponowano wprowadzenie alternatywnych trybów rozstrzygania sporów administracyjnych, czyli prostych i elastycznych procedur, szybkich, tanich, bardziej dyskretnych, w których polubowne działanie specjalistów respektuje słuszność, a nie tylko legalność sensu stricto ${ }^{6}$. Regulacje tej Rekomendacji wraz z innymi

${ }^{3}$ Z. Kmieciak, Stowo wstepne, w: Raport zespołu eksperckiego z prac w latach 2012-2016. Reforma prawa o postępowaniu administracyjnym, pod red. Z. Kmieciaka, Warszawa 2017, s. 13.

${ }^{4}$ J. Wegner-Kowalska, Mediacja, w: Raport zespołu eksperckiego z prac w latach 2012 $2016 \ldots$, s. 77.

${ }^{5}$ Recommendation Rec(2001)9 of the Committee of Ministers to member states on alternatives to litigation between administrative authorities and private parties.

${ }^{6}$ P. Sołtysiak, E. Wójcicka, Mediacja w postępowaniu przed wojewódzkim sądem administracyjnym, "Zeszyty Naukowe Instytutu Administracji AJD W Częstochowie. Gubernaculum et Administratio" 2012, nr 2(6), s. 30. 
aktami z zakresu soft-law, takimi jak Rekomendacje Komitetu Ministrów Rady Europy nr R (81) $7^{7}$ oraz nr R $(86) 12^{8}$, stworzyły, jak pisze Z. Kmieciak, europejskie standardy ADR, rozumiane jako powszechnie aprobowany wzorzec działania. Należy je rozpatrywać w kategoriach wskazań czy zaleceń dopuszczających znaczną swobodę w wyborze sposobów urzeczywistniania idei ADR 9 .

Problem ten należy rozpatrywać w szerszej perspektywie zapewnienia elastycznych standardów procedowania w sprawach administracyjnych. O potrzebie uelastycznienia procedury administracyjnej, która była jednym z celów ostatniej reformy Kodeksu postępowania administracyjnego, pisał także Z. Kmieciak, który zauważył, że intencją reformatorów było zapewnienie odpowiedniej efektywności procedurze administracyjnej i zmniejszenie w sposób odczuwalny społecznych kosztów jej uruchomienia, a generalnie - zerwanie z coraz bardziej anachronicznym, zarzuconym gdzie indziej, schematem regulacji, co odpowiada wizji sprawnego państwa. Autor powiązał te spostrzeżenia z rysującym się na świecie trendem kojarzonym z programami good governance: większej otwartości administracji, szerokiej partycypacji w jej poczynaniach różnych kategorii podmiotów, odchodzenia od wypełniania zadań publicznych w sposób właściwy dla struktur centralistycznych (common and control regulation) oraz maksymalnego odformalizowania podejmowanych w trybie urzędowym działań (ich uelastycznienia). Chodzi o eliminowanie zbędnej, wywołującej dotkliwe skutki dla budżetu państwa i budżetów jednostek samorządowych oraz powodującej znaczne uciążliwości dla jednostki mitręgi biurokratycznej ${ }^{10}$.

Elastyczność mediacji podejmowanych w trakcie postępowania administracyjnego zapewniona obecnymi przepisami k.p.a. oznacza $\mathrm{w}$ praktyce ich odformalizowanie. Toczą się one w trakcie postępowania, jednak ustawodawca zrezygnował ze ścisłej regulacji ich przebiegu, czego bezpośrednią konsekwencją jest możliwość takiego ich prowadzenia, by komunikacja między stronami mediacji przebiegała jak najsprawniej

\footnotetext{
${ }^{7}$ Rekomendacja z dnia 14 V 1981 r. o środkach ułatwiających dostęp do wymiaru sprawiedliwości (Recommendation No. R (81) 7 on Measures Facilitating Access to Justice).

${ }^{8}$ Rekomendacja z dnia 16 IX 1986 r. dotycząca środków zapobiegających nadmiernemu obciążeniu sądów i ograniczających to obciążenie (Recommendation No. R (86) 12 concerning measures to prevent and reduce the excessive workload in the courts).

${ }^{9} \mathrm{Z}$. Kmieciak, Postępowanie administracyjne i sadowoadministracyjne a prawo europejskie, Warszawa 2010, s. 173.

10 Z. Kmieciak, Słowo wstępne..., s. 13.
} 
i by możliwe było podejmowanie decyzji co do jej przebiegu zarówno przez mediatora, jak i przez strony mediacji - i jeżeli chodzi o kwestie "techniczne", i o sam proces porozumienia z punktu widzenia mechanizmów socjologicznych oraz psychologicznych. W mediacjach w postępowaniu administracyjnym możliwe jest więc zastosowanie szerokiego spektrum działań wiodących do osiągnięcia porozumienia. W związku z tym nie ma przeszkód, by mediacje toczyły się z wykorzystaniem elektronicznych środków komunikacji.

\section{2. "Odczarowanie" Internetu}

Trafnie zakres i częstotliwość wykorzystania elektronicznych narzędzi komunikacji ujmuje D. Fleszer. Jak słusznie zauważa ta autorka, nowoczesne technologie informacyjne jednocześnie stają się nowym medium komunikacyjnym. Jego głównymi zaletami są szybkość przepływu informacji i brak czasowego ograniczenia w ich korzystaniu (praktycznie 7 dni w tygodniu i 24 godziny na dobę). Dlatego też ich stosowanie staje się coraz powszechniejsze nie tylko w kontaktach towarzyskich, ale także w załatwianiu spraw, które do tej pory wymagały fizycznej obecności osoby zainteresowanej. Autorka pisze więc, że nie jest zaskoczeniem fakt, iż również od administracji publicznej społeczeństwo oczekuje unowocześnienia stosowanych procedur w ten sposób, aby możliwa stała się ich realizacja za pomocą Internetu ${ }^{11}$. Wiązać to można z ogólną tendencją panująca w społeczeństwie, kiedy to „obywatele i przedsiębiorcy przyzwyczaili się już do korzystania z komercyjnych produktów on-line i oczekują od swoich rządów i administracji ofert usług o wysokiej jakości i użyteczności. W miarę jak ujawniają się nowe możliwości technologiczne, zwiększa się liczba wyzwań na przyszłość, łatwy dostęp do kompleksowego, łatwego w obsłudze zestawu usług e-government jest marzeniem obywateli, przedsiębiorców i urzędników"12.

Cytowane wyżej poglądy trafiają w sedno problemu. W starszych opracowaniach zwracano uwagę na fakt swoistej "nieadekwatności”

${ }^{11}$ D. Fleszer, Funkcjonowanie elektronicznej administracji na przykładzie EPUAP, Roczniki Administracji i Prawa. Teoria i praktyka, rok XII, s. 119, http://www.humanitas.edu.pl/ resources/upload/dokumenty/Wydawnictwo/Roczniki\%20AiP\%20-\%20pliki/Podzielone/Roczniki\%20AiP\%202012/Fleszer.pdf (dostęp: 29 VI 2018).

12 A. Monarcha-Matlak, Obowiazki administracji w komunikacji elektronicznej, Warszawa 2008, s. 170, cyt. za: D. Fleszer, Funkcjonowanie elektronicznej administracji..., s. 126. 
stosowania możliwości, jakie daje Internet w kontaktach w sferze publicznej lub w pewnym zakresie spraw, o czym będzie mowa w dalszej części opracowania ${ }^{13}$. Natomiast obecny poziom zaawansowania technologicznego i rozwoju społecznego uzasadnia traktowanie komunikacji za pomocą Internetu jak każdej innej dostępnej formy wymiany informacji. Internet nie jest demonem, nie jest to "zaczarowana” sfera - wymiar nadrzeczywistości dostępny szamanom i "wybranym”. Nie powinno więc dziwić, że osoby, które na co dzień korzystają z bankowości elektronicznej, robią zakupy przez Internet oraz w ten sposób komunikują się np. z bliskimi oraz współpracownikami, będą oczekiwały szerokiego dostępu do elektronicznych metod komunikacji w ramach postępowań toczących się przed organami władzy publicznej. Internet to po prostu kolejny sposób porozumiewania się ludzi - narzędzie, za pomocą którego ludzkość realizuje swoją podstawową potrzebę utrzymywania kontaktów społecznych, znajdujące coraz więcej pól zastosowań, o czym świadczy chociażby dynamiczny rozwój e-administracji.

\section{Mediacje na tle tendencji rozwoju e-administracji}

Analizując europejskie tendencje w rozwoju społeczeństwa informacyjnego, K. Kłosowska zauważa, że wprowadzenie możliwie jak najszerszego pakietu usług administracji publicznej dokonywanych drogą elektroniczną jest zgodne z założeniami w pełni rozwiniętego społeczeństwa informacyjnego ${ }^{14}$. Nie da się zaprzeczyć, że współczesne społeczeństwo jest społeczeństwem informacyjnym, co dotyczy nie tylko ogromnego zasięgu wykorzystywania różnych form komunikacji, ale także znaczenia, jakie

${ }^{13}$ Na marginesie warto zauważyć, że studenci przygotowujący prace dyplomowe wśród wykazów źródeł umieszczanych na końcu pracy, takich jak wykaz literatury, aktów prawnych czy dokumentów urzędowych, często wydzielają jako osobną kategorię "źródła internetowe" niezależnie od tego, jakiego rodzaju jest to źródło: czy jest to artykuł naukowy opublikowany na stronie www, czy też materiał urzędowy, zupełnie jakby Internet odbierał tym materiałom powagi czy znaczenia lub jakby była to jakaś "specjalna" forma pozyskania danych. Autorzy tych prac to najczęściej bardzo młodzi ludzie, o których można by sądzić, że od lat przedszkolnych mieli kontakt z technologiami informatycznymi. Ta tendencja jest dowodem na to, że przynajmniej w polskim społeczeństwie wykorzystanie takich technologii budzi jeszcze pewne wątpliwości, a nawet nieufność.

${ }^{14}$ K. Kłosowska, Ewolucja czynności faktycznych administracji, w: Ewolucja prawnych form administracji publicznej. Księga jubileuszowa z okazji 60. rocznicy urodzin Profesora Ernesta Knosali, pod red. L. Zacharki, A. Matana, G. Łaszczycy, Warszawa 2008, s. 166-167. 
współcześnie ma informacja dla wszelkich aspektów życia i zaspokajania rozmaitych potrzeb ludzkich. Ponieważ celem administracji publicznej jest zaspokajanie ludzkich potrzeb, konieczne jest rozwijanie odpowiednich rozwiązań technologicznych w różnych aspektach jej działania.

Należy zgodzić się z D. Fleszer, która pisze, że rozwój e-administracji jest naturalną konsekwencją roli, jaką przypisuje się informatyzacji i rozwiązaniom informatycznym w społeczeństwie informacyjnym. Administracja musi wypracować metody, na nowo przyjrzeć się stosowanym procedurom pod kątem możliwości ich realizacji z wykorzystaniem komunikacji elektronicznej, a to z kolei wiąże się nade wszystko z jej uproszczeniem ${ }^{15}$. Rozwój kolejnych segmentów e-administracji jest więc nieunikniony, gdyż związany jest z dynamicznymi zmianami technologicznymi i społecznymi, jakie zachodzą w otoczeniu administracji, co powinno dotyczyć także możliwości wykorzystania elektronicznych technik komunikacyjnych w mediacjach dotyczących kwestii regulowanych prawem administracyjnym.

Jak zauważa D. Fleszer, efektem szerokiego wykorzystywania dostępnych narzędzi i technologii informatycznych przez administrację ma być wobec tego proste, pozbawione zbędnych formalności, a poza tym skuteczne, elektroniczne komunikowanie się obywatela z organem i, oczywiście, organu z obywatelem. Należy jednak podkreślić, że powstanie takiej sytuacji wymaga wysokiej świadomości kadr administracji, które najpierw same muszą przełamać stereotypowe podejście do sposobu załatwiania spraw, a w dalszej kolejności aktywnie działać dla podwyższenia świadomości o użyteczności elektronicznych rozwiązań wśród obywateli ${ }^{16}$. Oczywiście, muszą dysponować także odpowiednią wiedzą i możliwościami technicznymi - jeżeli chodzi o materialną bazę, taką jak odpowiedni sprzęt i oprogramowanie umożliwiające sprawne przesyłanie informacji z zachowaniem odpowiedniego standardu poufności i bezpieczeństwa transmisji danych. Konieczne jest także zagwarantowanie regulacji prawnych zarówno w sferze prawa powszechnie, jak i wewnętrznie obowiązującego, umożliwiających odpowiedni standard prowadzenia mediacji.

Jak zauważa G. Sibiga, pisząc o korzyściach zastosowania technologii informacyjno-telekomunikacyjnych w postępowaniu administracyjnym, znaczenie mają tu nie tylko korzyści przeliczalne finansowo, ale również

\footnotetext{
${ }^{15}$ D. Fleszer, Funkcjonowanie elektronicznej administracji..., s. 128.

${ }^{16}$ Ibidem.
} 
korzyści nieprzeliczalne finansowo, takie jak zwiększenie satysfakcji obywateli, polepszenie jakości i poprawności świadczonych usług czy poprawa reputacji administracji w społeczeństwie, a także zwiększenie zaufania do niej oraz gwarancji poufności przekazywanych informacji ${ }^{17}$.

Ponieważ rozwój technologiczny w ostatnich trzech dziesięcioleciach był bardzo dynamiczny i z pewnością pozostanie taki w przyszłości, należy się spodziewać dalszego rozwoju działań na rzecz rozwoju e-administracji w Polsce. Obecnie funkcjonująca Elektroniczna Platforma Usług Administracji Publicznej ePUAP, po uruchomieniu odpowiednich segmentów umożliwiających prowadzenie mediacji, mogłaby stać się platformą wykorzystywaną do tego typu działań. Jak to ujmują G. Wierczyński i W.R. Wiewiórowski, z organizacyjno-technicznego punktu widzenia ePUAP to wspólna infrastruktura udostępnienia przez jednostki administracji publicznej usług publicznych w kanałach elektronicznych w relacjach z obywatelami, przedsiębiorcami i innymi jednostkami administracji publicznej, także dlatego, że owa platforma obejmuje mechanizmy koordynacji usług publicznych świadczonych przez kilka podmiotów publicznych ${ }^{18}$. Wskazane byłoby więc wykorzystanie również do prowadzenia mediacji tego narzędzia, które jest już stosowane przez adresatów działań administracji publicznej. Nie ma jednak przeciwwskazań, by mediacje elektroniczne w postępowaniu administracyjnym toczyły się też w inny sposób, wykorzystujący możliwości, jakie daje prowadzenie komunikacji elektronicznej. Zdaniem J. Wegner-Kowalskiej przepisy Kodeksu regulujące mediację, stwarzając warunki do elastycznego funkcjonowania mediacji, mają charakter semiimperatywny. Instytucja ta daje duży zakres swobody osobom zainteresowanym w jej przeprowadzeniu, w tym co do kształtowania jej zasad oraz sposobu procedowania ${ }^{19}$, co należy rozpatrywać zarówno z punktu widzenia możliwości zastosowania swoistego scenariusza interakcji podczas mediacji adekwatnego do stanu sprawy i oczekiwań stron mediacji, jak i kwestii technicznych komunikacji.

${ }^{17}$ G. Sibiga, Komunikacja elektroniczna w postępowaniu administracyjnym - aktualny stan prawny, praktyka stosowania przepisów i dyskutowane kierunki dalszych zmian, w: Analiza i ocena zmian Kodeksu postępowania administracyjnego w latach 2010-2011, pod red. M. Błachuckiego, T. Górzyńskiej, G. Sibigi, Warszawa 2012, s. 103.

${ }^{18}$ G. Wierczyński, W.R. Wiewiórowski, Informatyka prawnicza. Technologia informacyjna dla prawników i administracji publicznej, Warszawa 2008, s. 352.

${ }^{19} \mathrm{~J}$. Wegner-Kowalska, Mediacja, s. 78. 


\section{Zastosowanie mediacji elektronicznych w sferze działania organów administracji publicznej}

Mediacje on-line wywodzą się ze Stanów Zjednoczonych ${ }^{20}$, ale także w Europie istnieją sprawdzone rozwiązania, których doświadczenia można by rozwinać $w$ mediacjach on-line w sprawach administracyjnych. Wypracowana przez lata praktyka prowadzenia mediacji za pomocą elektronicznych środków komunikacji, inaczej określanych jako mediacje on-line, toczące się $w$ ramach tzw. ODR (od anglojęzycznego skrótu on-line dispute resolution), pozwala na rozmaite kształtowanie ich przebiegu. Można je więc prowadzić za pomocą telekonferencji, wymiany e-maili albo kombinacji tych metod. Mediacje on-line mogą być też prowadzone $\mathrm{z}$ wykorzystaniem specjalnych platform mediacyjnych oferujących możliwość stosowania różnych form komunikacji, w tym prowadzenia ich za pomocą chat-roomów.

Jak pisze M. Wasylkowska-Michór, mediacje on-line mogą odzwierciedlać "tradycyjny" model mediacji, w którym strony i mediator w określonej sekwencji spotkań wspólnie ustalają sposób rozwiązania sprawy. Według tej autorki „Odzwierciedlenie to polega z reguły na tym, że np. maile kierowane są albo do dwóch stron, albo do każdej ze stron, bądź też negocjacje toczą się w wydzielonych dla każdej ze stron osobno, bądź też wspólnych tzw. chat-roomach". Można powadzić oddzielnie rozmowy z każdą ze stron, a jednocześnie na innej stronie internetowej może trwać wspólna sesja ${ }^{21}$.

${ }^{20}$ Jak podają G. Kaufmann-Kohler i T. Schultz, początki mediacji elektronicznej datuje się na rok 1996, co miało związek ze sporem, u którego podłoża tkwiły zarzuty o naruszenie praw autorskich przez osobę, która na własnej stronie internetowej podawała informacje czasem dosłownie zaczerpnięte z lokalnej prasy. W rozwiązanie tego sporu zaangażowano Biuro Rzecznika Praw Online (Online Ombuds Office), które działało w ramach pilotażowego projektu uruchomionego kilka miesięcy wcześniej w Centrum Technologii Informacyjnych Uniwersytetu w Massachusetts i Centrum Rozstrzygania Sporów w Amherst. W mediacji w tym przypadku najpierw doszło do wymiany e-maili, a następnie prowadzące ją osoby asystowały przy zawarciu ugody, co w sumie trwało około miesiąca. Sprawa zakończyła się współpracą stron mediacji. G. Kaufmann-Kohler, T. Schultz, Online Dispute Resolution: Challenges for Contemporary Justice, Hague 2004, s. 21-22, cyt. za: M. Wasylkowska-Michór, Mediacja elektroniczna w sprawach transgranicznych, w: Mediacje w społeczeństwie otwartym, pod red. M. Tabernackiej, R. Raszewskiej-Skałeckiej, Wrocław 2012, s. 283.

${ }^{21}$ M. Wasylkowska-Michór, Mediacja elektroniczna..., i cytowana tam publikacja: G. Kaufmann-Kohler, T. Schultz, Online Dispute Resolution..., s. 21-22. 
Wykorzystanie elektronicznych środków komunikacji następuje w wielu alternatywnych formach rozwiązywania sporów, co pozwala na zastosowanie także innych doświadczeń w elektronicznych mediacjach lub na tworzenie form hybrydowych wykorzystujących elektroniczna komunikację. Jak podają A. Kalisz i A. Ziemkiewicz, do popularnych form ODR, poza mediacją on-line, którą autorzy określają też jako e-mediację, należą negocjacje wspomagane (faciliated nagotiation), arbitraż on-line, ocena okoliczności (case appriasal), obsługa zażaleń (complaint handling), zautomatyzowane negocjacje (automated negotiation) oraz systemy wsparcia negocjacji (negotiation support systems) ${ }^{22}$.

Mediacje elektroniczne rozwijały się do tej pory przede wszystkim w obszarze rozwiązywania sporów w obrocie konsumenckim. Nie ma jednak przeszkód, by doświadczenia te wykorzystać w mediacjach w postępowaniu administracyjnym. Dotyczy to m.in. kwestii dopuszczalności prowadzenia mediacji. Należy ostrożnie podchodzić do prób wyodrębnienia pewnych "kategorii spraw", które uważa się za "mediowalne" bądź "niemediowalne" - zarówno jeżeli chodzi o możliwość poddania jakiegoś rodzaju spraw mediacjom jako takim, jak i zastosowanie w mediacjach metod komunikacji elektronicznej. Pamiętać należy, że to nie wyłącznie merytoryczny zakres problemu determinuje możliwość podjęcia mediacji, ale decydujące znaczenie ma przede wszystkim fakt pozostawania stron w sporze co do interpretacji faktów lub litery prawa i ich nastawienie do możliwości polubownego rozstrzygnięcia tych kwestii, w tym do zastosowania w tym zakresie metod ODR. Oczywiście, badania empiryczne mogą wskazywać na efektywność zastosowania alternatywnych metod rozwiązywania sporów w jakiejś "kategorii” spraw. Jak zauważa na podstawie przeprowadzonych przez siebie badań K. Mania, techniki ODR osiągają największą efektywność w przypadku sporów o niewielkim stopniu skomplikowaniaa ${ }^{23}$. Ale pamiętać należy, że efektywność rozwiązania problemu w sprawach administracyjnych należy rozpatrywać przede wszystkim w kategorii społecznych skutków mediacji, co w przypadku sporów w sprawach zawisłych przed organami administracji publicznej należy postrzegać przez pryzmat zasady

${ }^{22}$ A. Kalisz, M. Ziemkiewicz, Mediacja sadowa i pozasadowa. Zarys wykładu, Warszawa 2014, s. 37-38; zob. też powołany tam tekst: M. Araszkiewicz, A. Łopatkiewicz, Z. Zienkiewicz, Factor-based Parent Plan Support System, w: Proceedings of the Fourteenth International Conference on Artificial Intelligence and Law, ed. by E. Francesconi, B. Verheij, New York 2013, s. 171-175.

${ }^{23}$ A. Kalisz, M. Ziemkiewicz, Mediacja sądowa i pozasadowa..., s. 391. 
zaufania obywateli do państwa i związanego z tą zasadą standardu zapewnienia partycypacji społecznej w rozstrzyganiu spraw publicznych. Dlatego też zakres zastosowania ODR w postępowaniu administracyjnym jest tożsamy z zakresem spraw, jakie mogą być przedmiotem mediacji na podstawie przepisów k.p.a. Możliwość "zakwalifikowania” jakiejś sprawy do mediacji powinna być oceniana przede wszystkim w świetle regulacji przepisu z art. 96a § 3 Kodeksu, zgodnie z którym celem mediacji w postępowaniu administracyjnym jest wyjaśnienie i rozważenie okoliczności faktycznych i prawnych sprawy oraz dokonanie ustaleń dotyczących jej załatwienia w granicach obowiązującego prawa, w tym przez wydanie decyzji lub zawarcie ugody.

Ustawodawca w zasadzie pozostawił ocenie organu oraz stron zakres spraw, które mogą być poddane mediacjom. Wynika to przede wszystkim z art. $13 \S 1$ k.p.a., w którym jest mowa o tym, że działania organu zmierzające do przeprowadzenia mediacji powinny być podejmowane w sprawach, których charakter na to pozwala. Organ, kierując sprawę do mediacji, ma obowiązek dokonania oceny zasadności jej zastosowania na tym etapie postępowania, a w tym zakresie ma obowiązek brania pod uwagę takich czynników, jak m.in.: liczba stron w postępowaniu i to, z jakimi interesami one występują, nastawienie stron do kwestii możliwości osiągnięcia kompromisu, możliwość skorzystania z pewnego zakresu uprawnień dyskrecjonalnych w danej sytuacji prawnej i faktycznej, czyli w praktyce to, czy będzie możliwe rozważenie kilku dopuszczalnych prawnie opcji. Ponadto wpływ na skierowanie sprawy do mediacji będzie miało to, czy swoista sytuacja strukturalna organu umożliwi właściwą reprezentację w mediacjach lub akceptację ich wyniku w sprawach toczących się na etapie drugiej instancji, gdzie stronami mediacji są organ i adresat rozstrzygnięcia wydanego w pierwszej instancji ${ }^{24}$. Do mediacji w postępowaniu administracyjnym nadają się doskonale sprawy, w których następuje realizacja kompetencji o charakterze dyskrecjonalnym, tzn. takie, w których organ może wybrać $z$ różnych opcji przewidzianych przez prawodawcę w przepisach regulujących określone przypadki. Ponadto mediacje powinny znaleźć zastosowanie wszędzie tam, gdzie ujawniają się sprzeczne interesy stron $^{25}$. Te spostrzeżenia dotyczą także zakresu zastosowania mediacji z wykorzystaniem środków komunikacji elektronicznej. Dochodzą tu

\footnotetext{
${ }^{24}$ M. Tabernacka, Negocjacje i mediacje w sferze publicznej, Warszawa 2018, s. 122-123.

${ }^{25}$ Ibidem.
} 
jednakże pewne dodatkowe kwestie związane z nastawieniem stron do możliwości zastosowania tych środków, ich możliwości technologicznych, takich jak dostęp do Internetu i umiejętność skorzystania z odpowiednich narzędzi elektronicznych, oraz tego, czy organ administracji współpracuje $\mathrm{z}$ mediatorem dysponującym odpowiednim zapleczem technologicznym gwarantującym sprawność procesu komunikacji i poufność.

Dzięki temu, że w mediacjach on-line stosuje się kombinowane formy komunikacji bezpośredniej (za pomocą telekonferencji) i niebezpośredniej (za pomocą e-maili, list dyskusyjnych itp.), możliwe jest uelastycznienie procesu dochodzenia do porozumienia. Pozwala to na komunikację w dogodnym dla stron czasie niezależnie od tego, w jakim znajdują się one miejscu, bez potrzeby kontaktu w czasie rzeczywistym. Pewne światło na możliwości, jakie daje ten typ prowadzenia mediacji, rzuca opis mediacji zaczerpnięty ze strony internetowej kancelarii specjalizującej się m.in. w mediacji on-line, gdzie można przeczytać, że ten typ mediacji umożliwia prowadzenie mediacji na odległość, bez konieczności osobistych spotkań ze stronami. Przedstawiono tam wskazania do mediacji on-line. Wskazania te w istocie można traktować jako remedia na przeszkody prowadzenia mediacji w tradycyjnej formie bezpośrednich spotkań. Spośród katalogu wskazanego na tej stronie znaczenie w przypadku mediacji w sporach w postępowaniu administracyjnym mogą mieć: znaczna odległość miejsca zamieszkania/siedziby stron uniemożliwiająca spotkanie w jednym miejscu, pobyt za granica jednej ze stron, brak możliwości spotkania się stron w jednym terminie, brak możliwości przyjazdu na posiedzenie mediacyjne, np. ze względu na niepełnosprawność jednej ze stron, konieczność poczynienia ustaleń w bardzo krótkim czasie, niechęć lub obawę stron przed osobistymi spotkaniami. Jak to uściślono, dzięki mediacji on-line strony oddalone od siebie o setki czy tysiące kilometrów mają możliwość podjęcia próby szybkiego, polubownego rozwiązania sporu, bez straty czasu i ponoszenia kosztów związanych z dojazdami do miejsca spotkania. Jest to niewątpliwie podstawowa zaleta mediacji on-line ${ }^{26}$.

$\mathrm{W}$ mediacjach toczących się $\mathrm{w}$ ramach postępowania administracyjnego należy więc wziąć pod uwagę wykorzystanie możliwości, jakie daje zastosowanie dostępnych rozwiązań elektronicznych, o ile uprości to komunikację między stronami, a także wówczas, gdy istnieją szczególne

${ }^{26}$ Kancelaria mediacyjna i prawna Grażyna Górska, Wskazania do mediacji on-line, http://mediator-olawa.pl/oferta/platforma-dla-mediacji-online (dostęp: 2 VII 2018). 
względy natury obiektywnej lub subiektywnej będące przeciwwskazaniem do osobistego kontaktu, a nawet wtedy, gdy mimo braku przeciwwskazań do osobistego spotkania stron wykorzystanie elektronicznych środków komunikacji na odległość przyniesie wymierne korzyści, takie jak oszczędność nakładów finansowych czy oszczędność czasu.

$\mathrm{W}$ mediacjach on-line konieczne jest wsparcie techniczne i jeżeli nie zapewnia tego organ administracji, w grę wchodzi wykorzystanie wsparcia zewnętrznego, dlatego też - o czym pisze M. Wasylkowska-Michór mediator może posiadać własny serwis do prowadzenia mediacji lub też może korzystać z usług dostawcy technologii (np. właściciela strony internetowej, który oferuje narzędzia umożliwiające przeprowadzenie mediacji) i który jako niezależny dostawca narzędzi umożliwiających przeprowadzenie mediacji on-line oferuje swoje usługi e-mediatorom ${ }^{27}$, którzy mogą współpracować z instytucjami zlecającymi mediacje.

Jak prognozuje M. Wasylkowska-Michór, w przyszłości, kiedy e-mediacja stanie się bardziej powszechna, rola serwisów usług mediacyjnych on-line wzrośnie, gdyż mediatorom nie będzie się opłacało tworzenie własnych serwisów ze względu na duże koszty związane przede wszystkim z koniecznością zagwarantowania bezpieczeństwa danych przy stosunkowo niewielkiej liczbie obsługiwanych przez nich spraw ${ }^{28}$.

Na gruncie obecnych rozwiązań kodeksowych można się spodziewać upowszechnienia praktyki powierzania mediacji zewnętrznym mediatorom wykonującym ten zawód poza strukturą administracji publicznej ${ }^{29}$. Zarówno w tym przypadku, jak i w przypadku korzystania

${ }^{27}$ M. Wasylkowska-Michór, Mediacja elektroniczna..., s. 287, i cytowany tam: S.H. Bol, An Analysis of the Role of Different Players in E-mediation: The (Legal) Implications, s. 23-24, http://www.odr.info/monthly/5th\%20Party\%20-\%20Bol.pdf (dostęp: 23 XI 2011).

${ }^{28}$ M. Wasylkowska-Michór, Elektroniczna mediacja - mit czy rozwiazanie na przyszłość?, https://nawokandzie.ms.gov.pl/numer-5/elektronizacja-postepowan/elektronicznamediacja-mit-czy-rozwiazanie-na-przyszlosc.html, publikacja: 19 IV 2011 r. (dostęp: 24 VI 2018).

${ }^{29}$ Obowiązujące przepisy k.p.a. ustanawiają standard swobody wyboru mediatora przez strony. Zgodnie z art. 96d § $2 \mathrm{w}$ postanowieniu o skierowaniu sprawy do mediacji wskazuje się mediatora wybranego przez uczestników mediacji, a jeżeli uczestnicy mediacji nie wybrali mediatora, wskazuje się mediatora wybranego przez organ administracji publicznej, posiadającego odpowiednią wiedzę i umiejętności w zakresie prowadzenia mediacji w sprawach danego rodzaju. Ponadto przepis art. 96f k.p.a. określa wymogi, którym powinna odpowiadać osoba powołana do pełnienia funkcji mediatora w określonej sprawie. Z $\S 2$ tej regulacji wynika, że w sytuacji, gdy uczestnikiem mediacji jest organ prowadzący postępowanie, mediatorem może być wyłącznie osoba wpisana na listę stałych mediatorów lub do wykazu instytucji i osób uprawnionych do prowadzenia postępowania mediacyjnego, prowadzonych przez prezesa sądu okręgowego, 
z zewnętrznych platform mediacyjnych oferujących usługi w zakresie ODR zastosowanie znajdą przepisy ustawy o świadczeniu usług drogą elektroniczną. Ustawa ta definiuje w art. 2 pkt 6 usługodawcę usług elektronicznych jako osobę fizyczną bądź osobę prawną albo jednostkę organizacyjną nieposiadającą osobowości prawnej, która prowadząc, chociażby ubocznie, działalność zarobkową lub zawodowa, świadczy usługi drogą elektroniczną. Natomiast zgodnie z art. 2 pkt 4 tego aktu świadczenie usługi drogą elektroniczną to wykonanie usługi świadczonej bez jednoczesnej obecności stron (na odległość), poprzez przekaz danych na indywidualne żądanie usługobiorcy, przesyłanej i otrzymywanej za pomocą urządzeń do elektronicznego przetwarzania, włącznie z kompresją cyfrowa, i przechowywania danych, która jest w całości nadawana, odbierana lub transmitowana za pomocą sieci telekomunikacyjnej w rozumieniu Ustawy z dnia 16 lipca 2004 r. - Prawo telekomunikacyjne ${ }^{30}$.

Należy więc zauważyć, że zarówno mediator organizujący platformę ODR wykorzystywaną w mediacjach administracyjnych, jak i dostawca takich usług będą traktowani jako usługodawcy w świetle przepisów tej ustawy.

\section{Proceduralne aspekty mediacji elektronicznych w postępowaniu administracyjnym}

Przepis art. 96k k.p.a. umożliwia swobodne projektowanie przebiegu mediacji, co realizuje ustawowe założenia tej metody rozwiązywania sporów w postępowaniu administracyjnym określone w art. 13 \& 2 k.p.a. W tej z kolei regulacji jest mowa o podejmowaniu "wszelkich uzasadnionych" na danym etapie postępowania czynności "umożliwiających przeprowadzenie mediacji lub zawarcie ugody". Konsekwencją

lub mediator wpisany na listę prowadzoną przez organizację pozarządową lub uczelnię, o której informację przekazano prezesowi sądu okręgowego. Ponadto, zgodnie z § 3 omawianej tu regulacji, mediatorem nie może być pracownik organu administracji publicznej, przed którym toczy się postępowanie w sprawie. Nawet więc jeżeli w świetle § 1 omawianego tu artykułu dopuszczalne jest, by np. w mediacjach toczących się między stronami funkcje mediatora pełnił pracownik organu administracji publicznej (ale nie tego, przed którym toczy się postępowanie), to prawdopodobnie, ze względu na dążenie do profesjonalizacji przebiegu postępowania administracyjnego, organy administracji publicznej będą kierowały sprawy do zewnętrznych mediatorów.

${ }^{30}$ Tekst jedn. Dz.U. 2017, poz. 1907 ze zm. 
zastosowania takich pojęć przez ustawodawcę jest możliwość podjęcia każdej formy komunikacji, w tym takiej, która będzie przebiegała za pomocą środków elektronicznych. Zgodnie z regulacją art. 96k k.p.a. "Mediator prowadzi mediację, dążąc do polubownego rozwiązania sporu, w tym przez wspieranie uczestników mediacji w formułowaniu przez nich propozycji ugodowych". Ani w tym przepisie, ani w następnych odnoszących się do kwestii proceduralnych nie wskazano więc szczególnego sposobu ani miejsca, w którym miałaby się toczyć. Wybór zastosowania elektronicznej formy prowadzenia mediacji zależy zatem od stron i mediatora, ponadto nie ma przeszkód, by wobec braku sprzeciwu tych podmiotów był inspirowany przez organ administracji kierujący sprawę do mediacji. W obecnym stanie prawnym dokonanie wyboru takiej formy komunikacji możliwe jest w dowolnym momencie trwania mediacji i w praktyce może ograniczać się tylko do pewnych kwestii, np. przesłania projektu tekstu ustaleń mediacyjnych do akceptacji stronom albo mediatorowi. Po wydaniu postanowienia o skierowaniu sprawy do mediacji organ administracji przekazuje mediatorowi dane kontaktowe uczestników mediacji oraz ich pełnomocników, jeżeli je posiada. Jak stanowi art. 96h k.p.a., są to w szczególności numery telefonów i adresy poczty elektronicznej. Nie ma więc przeszkód, aby, o ile organ dysponuje adresami poczty elektronicznej, mediator w początkowej fazie mediacji mógł kontaktować się ze stronami właśnie drogą elektroniczną.

Z kwestią "organizacji” kontaktu stron i mediatora rysują się jeszcze trzy interesujące kwestie proceduralne. Na gruncie obowiązujących przepisów nie jest dopuszczalne prowadzenie mediacji zautomatyzowanych, czyli takich, którymi kieruje algorytm, gdyż nie występuje w nich mediator będący osobą fizyczną, bądź też takich, w których nie będzie można zidentyfikować konkretnego mediatora. W warunkach obecnej regulacji kodeksowej mediacje nie mogłyby się zatem toczyć przy wykorzystaniu platformy obsługiwanej automatycznie, konfrontującej i wybierającej za pomocą algorytmów określone opcje rozwiązań albo wówczas, gdy nad tym procesem czuwałby niespersonalizowany zespół osób pełniących faktycznie funkcje mediatora. Mediator jest osobą odpowiedzialną za przebieg i efekt mediacji. Jest to jego odpowiedzialność osobista.

Brak możliwości zautomatyzowania procesu mediacji jest przede wszystkim konsekwencją regulacji art. $96 \mathrm{f} \S 1$ k.p.a., zgodnie z którym mediatorem może być: osoba fizyczna, która posiada pełną zdolność do czynności prawnych i korzysta z pełni praw publicznych, wpisana na 
listę stałych mediatorów lub do wykazu instytucji i osób uprawnionych do prowadzenia postępowania mediacyjnego, prowadzonych przez prezesa sądu okręgowego. O tym, że mediacje muszą być prowadzone przez konkretnego mediatora, przesądzają też inne regulacje kodeksowe określające obowiązki i uprawnienia mediatora. Przepis art. 96d § 1 k.p.a. określa spoczywający na mediatorze obowiązek pomocy stronom $\mathrm{w}$ formułowaniu propozycji ugodowych. Nawet jeżeli udałoby się opracować stosowne algorytmy, które teoretycznie mogłyby zastąić w tym człowieka, to wyjaśnienie stronom przesłanek i konsekwencji wyboru określonych opcji, wobec braku możliwości przetwarzania informacji zwrotnych i faktycznego braku możliwości sprawdzenia, czy strony właściwie rozumieją sens dokonywanych przez siebie wyborów, wyklucza możliwość prowadzenia zautomatyzowanych mediacji w postępowaniu administracyjnym.

Należy zwrócić także uwagę na pewne proceduralne kwestie związane ze sporządzeniem protokołu postępowania mediacyjnego. Regulacja art. 96m § 2 k.p.a. określa obowiązki mediatora związane ze sporządzeniem protokołu $\mathrm{z}$ mediacji. $\mathrm{W}$ punkcie pierwszym tego przepisu jest mowa o tym, że protokół zawiera informację o czasie i miejscu przeprowadzenia mediacji. Nie ma przeszkód, by zawrzeć w protokole informacje o tym, że mediacje odbyły się $\mathrm{w}$ formie telekonferencji i wskazać, gdzie znajdowała się wówczas każda ze stron ${ }^{31}$, lub opisać procedurę korzystania ze środków komunikacji elektronicznej. Należy jednak zauważyć, że ze względu na dotychczasową praktykę działania instytucji publicznych osoby zatrudnione w strukturach administracji mogą mieć z tym pewien "mentalny” problem. Punkt piąty art. 96m $\S 2$ k.p.a. określa, że protokół zawiera podpis mediatora, a jeżeli którykolwiek z uczestników mediacji nie może złożyć swojego podpisu - wzmiankę o przyczynie braku podpisu. Sytuacje, gdy uczestnik lub uczestnicy mediacji znajdują się gdzie indziej niż mediator i dlatego nie są w stanie złożyć podpisu, nie powinny być traktowane jako przeszkoda do sporządzenia tego dokumentu, a brak podpisu stron $\mathrm{w}$ takim wypadku nie powinien być interpretowany jako wada dokumentu, o ile oczywiście będzie na nim zawarta stosowana wzmianka o przyczynie braku odręcznego podpisu. Należy więc uznać, że podpis mediatora i stosowane wzmianki są tu wystarczające. Natomiast gdyby możliwe było wykorzystanie $w$ trakcie mediacji platformy ePUAP, nie

\footnotetext{
${ }^{31}$ M. Tabernacka, op. cit., s. 39-40.
} 
byłoby przeszkód, by protokół był przekazywany organowi w formie elektronicznej za pomocą tej platformy, a jej wykorzystanie również umożliwiałoby złożenie podpisów w sposób właściwy dla tego systemu.

Istotną kwestią proceduralną jest także zapewnienie wysokiego standardu poufności prowadzenia mediacji, jaki wymagany jest przepisami Kodeksu. Zgodnie z art. 96j § 1 k.p.a. mediacja nie jest jawna. Przepis § 2 tej regulacji nakłada na mediatora oraz uczestników mediacji i na inne osoby biorące w niej udział obowiązek zachowania w tajemnicy wszelkich faktów, o których dowiedziały się one w związku z prowadzeniem mediacji, chyba że uczestnicy mediacji postanowią inaczej. Dodatkowo $\S 3$ ustanawia zakaz wykorzystania po zakończeniu mediacji propozycji ugodowych, ujawnionych faktów lub oświadczeń złożonych w jej toku, $\mathrm{z}$ wyjątkiem ustaleń, które zostały zawarte w protokole z przebiegu mediacji. Oznacza to konieczność stosowania rozwiązań technologicznych zapewniających bezpieczeństwo dostępu stron i mediatora do kanałów transmisji i danych przechowywanych na nośnikach. Konieczna jest możliwość wykluczenia rejestrowania transmitowanego obrazu lub rozmów. Zauważyć jednak należy, że ryzyko "wypłynięcia danych" nie jest znacząco większe niż w klasycznych mediacjach, w których może dojść do prób kopiowania papierowych wersji dokumentów oraz prób nagrywania przebiegu rozmów przez uczestników mediacji bez zgody innych uczestników. Ustawowy zakaz wykorzystania takich danych ma tę konsekwencję, że wykorzystanie informacji pozyskanych i ewentualnie utrwalonych niezgodnie $z$ regulacjami k.p.a. jest nielegalne.

\section{Podsumowanie}

Wykorzystanie w mediacjach w postępowaniu administracyjnym elektronicznych środków komunikacji może następować w takim samym zakresie jak mediacji klasycznych - toczących się przy bezpośrednim udziale mediatora i stron. Wykorzystanie komunikacji on-line w mediacjach regulowanych przepisami k.p.a. uzależnione jest od możliwości technicznych organu, mediatora i stron mediacji oraz od woli jej uczestników. Komunikacja elektroniczna może być traktowana jako wsparcie rozmów toczących się podczas mediacji, ale w pewnych okolicznościach, takich jak np. obiektywne trudności w osobistym kontakcie, może zastąpić bezpośrednie spotkania w jednym miejscu. Należy oczekiwać coraz szerszego zakresu wykorzystania tej formy prowadzenia rozmów 
i dokonywania ustaleń w trakcie mediacji przede wszystkim dlatego, że umożliwiają one znaczną oszczędność czasu i nakładów. Obecnie funkcjonujące $\mathrm{w}$ sferze działania administracji publicznej rozwiązania techniczne, takie jak platforma ePUAP, mogłyby, po odpowiednim przystosowaniu, być wykorzystywane z powodzeniem jako narzędzie prowadzenia mediacji on-line.

\section{THE USE OF ELECTRONIC COMMUNICATION IN PUBLIC ADMINISTRATION MEDIATION}

\section{Sum mary}

In the light of the applicable regulations governing administrative proceedings, electronic communication is an acceptable form of communication between the authority and other parties in the area of activities regulated by the provision of Article 13 of the Act of 14 June 1960, the Code of Administrative Procedure, in its current wording. Since this provision provides for the use of mediation in the resolution of disputes relating to the settlement of matters which are the subject of administrative proceedings in the first and second instance, electronic communication may also be used in mediation at both stages of the administrative proceedings. The mediation process itself may be carried out using Internet means of communication, and the mediator may in the same way contact the body referring the case to mediation.

Teleconferencing and other methods of electronic communication, such as e-mails, chat-rooms and teleconferences, are all possible under the current legal framework. However, it is not allowed to conduct automated mediation, i.e. mediation in which identification of a specific mediator will not be possible. In the light of current legislation in force, a mediator must be involved in the supervision of the mediation process and be responsible for its course. This is the personal responsibility of the mediator.

The trend to use electronic communication in the public sphere will continue. This will apply both to the communication within the internal structures of the administration and to its external relations. The development of e-administration may also facilitate the development of ADR (Alternative Dispute Resolution) methods in administrative proceedings. This corresponds to the global trend where the methods and procedures of administration are being adopted to the environment which is increasingly using different forms of electronic communication.

Keywords: mediation - Internet - electronic communication - de-formalisation 